\title{
molecules
}

ISSN 1420-3049

(C) 2008 by MDPI

www.mdpi.org/molecules

Full Paper

\section{Chemical Composition of Ground Pearl (Eurhizococcus colombianus) Cysts}

Winston Quiñones ${ }^{1}$, Bernardo Vicente ${ }^{1}$, Fernando Torres ${ }^{1}$, Rosendo Archbold ${ }^{1}$, Walter Murillo ${ }^{1}$, Martha Londoño ${ }^{2}$ and Fernando Echeverri ${ }^{1}{ }^{1 *}$

${ }^{1}$ Grupo de Química Orgánica de Productos Naturales, Universidad de Antioquia-SIU, Medellin, Colombia

${ }^{2}$ Corporación Agropecuaria Colombiana-CORPOICA, La Selva, Rionegro-Colombia

* Author to whom correspondence should be addressed; E-mail: echeveri@quimbaya.udea.edu.co; Tel.: +574 2106595, Fax.: +574 2106565.

Received: 4 December 2007; in revised form: 21 January 2008 / Accepted: 28 January 2008 / Published: 29 January 2008

\begin{abstract}
Ground pearl (Eurhizococcus colombianus) is a crop pest in Colombia, with special impact on fig, grass, rubus and tomato plants. The insect is resistant to external insecticide application because it produces a thick waxy shell that isolates it from the environment. The composition of this shell was determined by NMR and MS as a triglyceride, whose fatty acid is transformed into other products with the metamorphosis of the insect. Additionally, several enzymatic inhibitors were assayed to control the insect with negative results.
\end{abstract}

Keywords: Ground Pearl, insect, cyst, triglyceride, metabolism.

\section{Introduction}

Eurhizococcus colombianus Jakubsky (Homoptera-Margarodidae), known as ground pearl, is a polyphagous insect that lives on the roots of several crops (rubus, fig, grass, avocado, feijoa, apple, peach and tomato plants, among others) and several brush spp. belonging to the genus Rumex and weeds [1,2]. The first report about the presence of this pest in Colombia incorrectly identified it as Eurhizococcus braziliensis [3], but later it was established as a new species, E. colombianus, by 
Jakubsky [4]. The related insect, Eurhizococcus braziliensis, which mainly attacks grapevines and sugar cane crops, has been recorded in 62 plant species in Brazil [5], Chile, and South Africa [6,7].

The insect's life cycle includes several stages [8] (Figure 1). In the nymph stage E. colombianus is attached to the roots by means of a sucking apparatus. Later in its life cycle, the insect secretes a thick waxy substance to form a cyst which is resistant to external insecticide application [9,10]; this latent life stage is typical for a long period of time of the insect's life. From cysts, new females and male larva hatch.

Figure 1. Stages in the Development of Eurhizococcus colombianus.

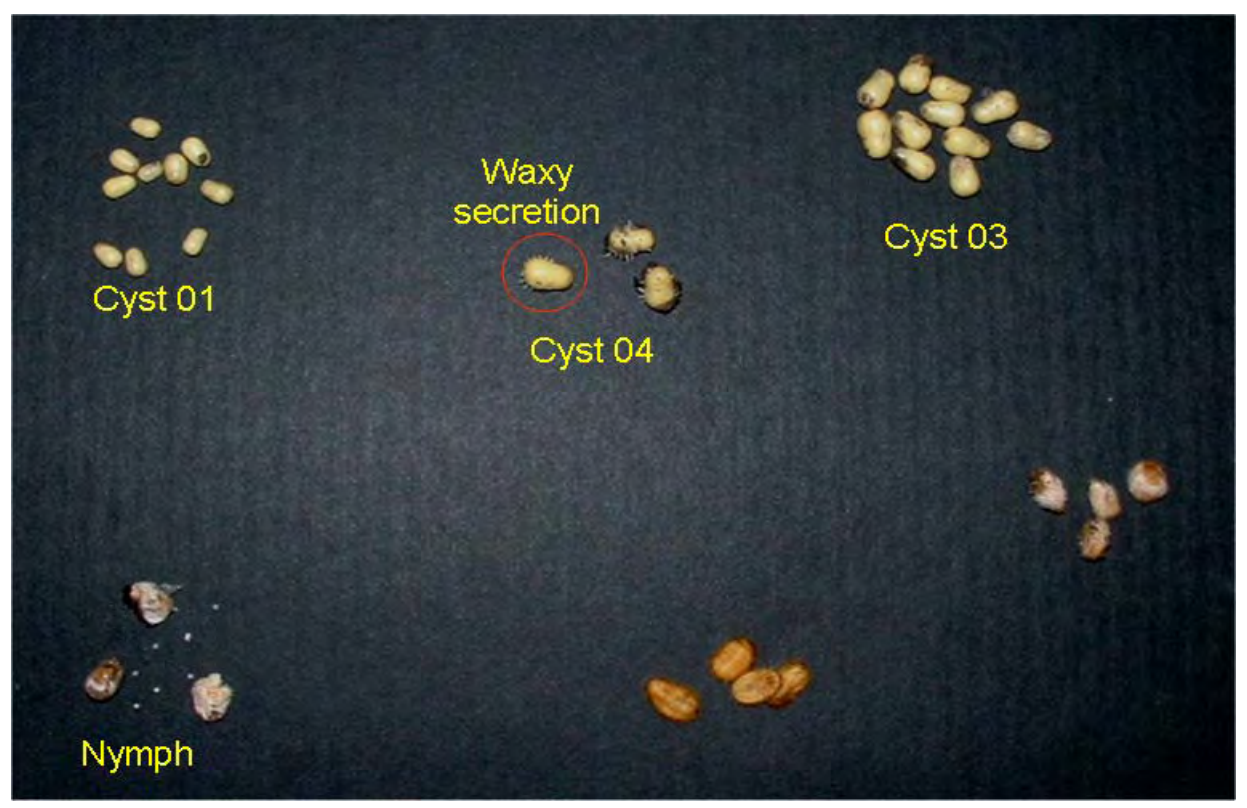

The plants affected by ground pearl show a reduction of growth rate and crop production. Ground pearl kills the plant within several months, probably by sap loss or viral infection. In Colombia a rubus crop was destroyed by ground pearl infestation. Several treatments were used in the past to control the insect, including chemigation. The most effective compound was metidathion, which caused a $83.3 \%$ mortality of the insect after five months [11].

Biochemical composition about the waxy material could be important information to design new and more effective methods to control E. colombianus. In this paper, we report the structure of the main product of the cyst wax and, additionally, spectroscopic evidence of its transformation into a polymeric material through several reductive steps.

\section{Results and Discussion}

The analysis of the main compound of the cyst was carried out by NMR. The ${ }^{1} \mathrm{H}-\mathrm{NMR}$ spectra of crude extract showed a triplet at $\delta 0.85(3 \mathrm{H})$, an intense singlet at $\delta 1.3$ ( $\mathrm{nCH}_{2}$ groups), and other signals integrating for $2 \mathrm{H}$ at $\delta 1.6,2.0,2.3,4.3$ and 4.1, respectively. Additionally other signals at 5.3 $(2 \mathrm{H})$ and $5.25(1 \mathrm{H})$ were detected. These data indicate the presence of a triglyceride with two unsaturated fatty acid chains and a saturated moiety. Mass spectrometry indicated a m.w. of 886.9576 with fragments at m/z $605.8720\left(\mathrm{M}^{+}\right.$- oleate), $340.2385\left(\mathrm{C}_{21} \mathrm{H}_{40} \mathrm{O}_{3}\right), 283.0400\left(\mathrm{C}_{18} \mathrm{H}_{35} \mathrm{O}_{2}\right), 281.0856$ $\left(\mathrm{C}_{18} \mathrm{H}_{33} \mathrm{O}_{2}\right)$, and $265.4199\left(\mathrm{C}_{18} \mathrm{H}_{33} \mathrm{O}\right)$. 
Additionally, changes in the chemical composition with time were observed by NMR spectroscopy (Figure 2); thus, at the beginning of the insect cycle, the chemical composition of the cyst is based on triglycerides, as mentioned above. However, in the next stage, the amount of unsaturated triglycerides (signals between 5.0-6.5 ppm) is low and formation of unsaturated diglycerides can be observed, in addition to a new compound, possibly an aldehyde, as it can be deduced from the weak signal at 9.85 ppm. Finally, in the last insect development stages, only saturated hydrocarbon signals appear in the spectra.

Figure 2. ${ }^{1} \mathrm{H}-\mathrm{NMR}$ spectra of the cyst, increasing development stages (less to more advanced, 01-04) and external cyst film.

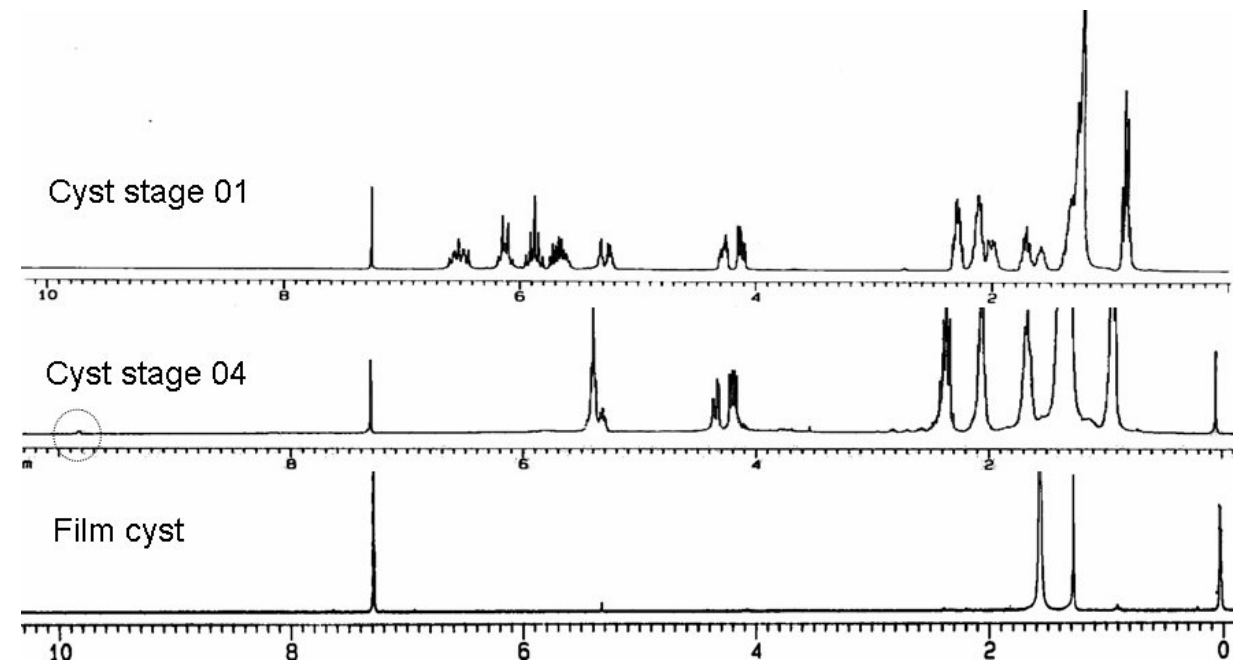

It seems therefore that hydrolysis of the triglyceride produces a fatty acid, in addition to a diglyceride and then the former compound is subsequently reduced to an aldehyde and later to a hydrocarbon. These results are in disagreement with those previously reported by Willkins, who found short chain fatty acids in E. braziliensis by means of HPLC [12]; however, an alternative pathway for the degradation of the fatty acid could involve an oxidative process to produce valeric acid as an artifact of the oxidation of unsaturated fatty acids.

The effects of the fatty acid biosynthesis inhibitors were negative due to the advanced stages of the insects. The presence of the waxy material could block the absorption of inhibitors. The application of these inhibitors could be more effective in the first larvae stages, when the insect does not have any protection against external conditions.

There are two important aspects related to the biochemistry of the E. colombianus. Firstly, due to an efficient chemical reduction process from a fatty acid to a long hydrocarbon; secondly, the ability to stabilize unsaturated triglycerides and fatty acids in the soil, a wet environment with metals, that normally catalyzes their oxidative degradation.

The knowledge about chemical composition of the cyst and transformation of their products can be used to control the insect through the application of inhibitors of fatty acid biosynthesis, especially when eggs are hatching, or in the larvae stage, since the lipidic shell has not still formed. 


\section{Experimental}

\section{General}

Sephadex LH-20 with hexane- $\mathrm{MeOH}-\mathrm{CH}_{2} \mathrm{Cl}_{2}(2: 1: 1, \mathrm{v} / \mathrm{v})$ as eluent was used for column chromatography. NMR spectroscopic analysis was performed on a Bruker AMX-300 spectrometer (300 MHz for ${ }^{1} \mathrm{H} ; 75 \mathrm{MHz}$ for ${ }^{13} \mathrm{C} ; \mathrm{CDCl}_{3}$ ), chemical shifts (ppm) using TMS as internal standard, with coupling constant being reported in Hz, EIMS data were determined on a JEOL JMS-AX505HA mass spectrometer at $70 \mathrm{eV}$, FABMS were obtained on a JEOL JMS-SX102A mass spectrometer with nitrobenzyl alcohol.

\section{Insect collection}

Eurhizococcus colombianus at several growth stages were collected four times during 2004 and 2005, on figs and rubus crops and were identified by Imre Foldi (Museum National d'Histoire Naturelle, Laboratoire d'Entomologie \& E.P 90 du CNRS, Paris, France) and maintained in Petri dishes with wet land at dark. Additionally, insects in several stages were collected and extracted with solvents as described below.

\section{Isolation}

Insect were classified according to their size and stage. Approximately 30 cysts (1.06 g) were immersed in chloroform for 5 minutes and then in a dichloromethane-methanol mixture for the same time; after that the solvents were evaporated in vacuo. In addition, the external film of the other 30 pearls were removed with a scalpel and immersed in chloroform and later, in the same cyst secretion, they were also collected and worked up. All crude extracts from cysts from several stages and external film were subjected to column chromatography on Sephadex LH-20. The main component was collected and submitted to NMR and MS analysis without derivatization.

\section{Effects of inhibitors.}

Twenty cysts of E. colombianus were immersed for one minute in water solutions of isoniazid, trichlosan and ethionamide at 100, 200, 300 and 500 ppm, with Tween 20 (2\%); observations were made at days $8,15,25$. At the end of the experiments, cysts were extracted and their chemical composition compared with the extracts of untreated cysts through tlc and HPLC. Surviving cysts were observed because they maintained their yellow color. Besides, if lipidic covering is manually removed, the insect begins to produce a new cover.

\section{Acknowledgements}

The authors thank Colciencias, Universidad de Antioquia and Corpoica for financial support; WM acknowledge Colciencias for a fellowship. 


\section{References}

1. Castrillon, A.C.; Urrea, J.; Guevara, M.N.; Pineda, H. Algunos aspectos biomorfológicos y agroecológicos de la perla de tierra en la zona agroecológica. In: Memorias $3^{\circ}$ Seminario de frutales de clima frío moderado. Centro de Desarrollo Tecnológico de Frutales: Manizales (Colombia). 2000; p. 86.

2. Castrillon, A. C.; Urrea, C.F.; Guevara, N.J.; Pineda, S. M. Hospederos de la perla de tierra (Eurhizococcus spp.) en areas frutícolas de clima frío moderado del departamento de Caldas. Corporación Colombiana de Investigación Agropecuaria (CORPOICA): Rionegro Colombia, 1998.

3. Figueroa, A. Catalogación inicial de las cochinillas del Valle del Cauca (Homóptera: Coccoidea). Rev. Fac. Nac. Agron. (Colombia) 1946, 6, 196-220.

4. Jakubski, A.W. A critical revision of the families Margarodidae and Termitococcidae (Hemiptera, Coccoidea). Trustees of the British Museum (Natural History): London, 1965.

5. Foldi, I.; Soria, S.J. Les cochenilles nuisibles àla vigne en Amérique du Sud (Homoptera: Coccoidea). Annals. Soc. Ent. Fr. (N.S). 1989, 25, 411-430.

6. Fauré, G.O.; Pinto J.C. Pest of grapevine in Chile. F.A.O. Plant Prot. Bull. 1959, 7, 73-77.

7. De Klerk, A.C. Biology of Margarodes vredendalensis De Klerk (Coccoidea: Margarodidae). South Afr. J. Enol. Vitic. 1980, 1, 47-58.

8. Guarin, J. H. Como se dispersa la perla de tierra. Eurhizococcus colombianus. Corporación Colombiana de Investigación Agropecuaria (CORPOICA): Rionegro, Colombia. 2002.

9. González, R.; Hiroshi, K.; Marin, A.; Hughes, P. Biología y ensayos preliminares de control del margarodes de la vid, Margarodes vitis (Philippi). Agric. Téc. 1969, 29, 93-123.

10. Botton, M.; Hickel, E.R.; Soria, S.J.; Teixeira, I. Bioecologia e controle da Pérola-da-terra Eurhizococcus brasiliensis (Hemiptera: Margarodidae) na cultura da videi. Circular Técnica (EMBRAPA) 2000, 27, 1-23.

11. Hickel, E. R.; Peruzzo, E. L.; Schuck, E. Controle da pérola-da-terra, Eurhizococcus brasiliensis (Hempel) (Homoptera:Margarodidae), através da insetigação. Neotrop. Entomol. 2001, 30, 127132.

12. Willkins, J. G.; Soria, S. J. Identification by gas chromatography-mass spectrometry (GC -MS) of the compounds responsible for the rancid odor of female cyst of Eurhizococcus brasiliensis (Hempel). Ann. Soc. Entomol. Brasil 1996, 25, 169-170.

Sample Availability: Samples of the triglicerides and hydrocarbon are available from authors.

(c) 2008 by MDPI (http://www.mdpi.org). Reproduction is permitted for noncommercial purposes. 